\title{
Constraints in Adoption of Vegetables Production Technology in Nellore District of Andhra Pradesh, India
}

\author{
D. Vinod Naik ${ }^{1 *}$, M. Kavitha ${ }^{2}$ and R.V.S.K. Reddy ${ }^{3}$
}

${ }^{1}$ Agril. Extension, Krishi Vigyan Kendra, Periyavaram, Venkatagiri, Nellore Dist, A.P, India

${ }^{2}$ Krishi Vigyan Kendra, Periyavaram, Venkatagiri, Nellore Dist, A.P., India

${ }^{3}$ Director of Extension, Dr. Y.S.R. Horticultural University, V.R. Gudem, A.P., India

*Corresponding author

\section{A B S T R A C T}

The present study was conducted in Nellore district of Andhra Pradesh in the year of 2018-19. Out of 43 mandals, only 5 mandals was purposely selected.

Keywords

Vegetables,

Constraint,

Production

technology, IPM

technologies

Article Info

Accepted:

26 July 2019

Available Online:

10 August 2019
From these mandals 12 villages were randomly selected, from these villages 8 vegetables growers were selected from each village by simple random sampling method. Thus the total numbers of 96 vegetables growers were selected. Average productivity of vegetables crop in Nellore is very low (98.72 q. /ha.) and far from the national average yield of $17 \mathrm{mT} . / \mathrm{ha}$. It is mainly because of poor knowledge as well as adoption of scientific technologies of vegetable cultivation. A wide gap exists between the yields obtained and the potential yields. By adopting improved varieties and technologies, the production and productivity can be increased. Promotion of hybrid vegetable technology or improved varieties is major strategy for increasing productivity. The major constraints could be detected to vegetable production technology like non-remunerative price $(95.83 \%)$, lack of irrigation facilities $(94.79 \%)$, lack of knowledge of IPM technologies and lack of subsidy (91.66\%).

\section{Introduction}

Average productivity of vegetables crop in Nellore District of Andhra Pradesh is (97.32q./ha.) very low (97.32q.ha ${ }^{-1}$ ) and far from the national average yield of 154.6 q. ha ${ }^{-1}$. It is mainly because of poor knowledge as well as adoption of scientific technologies of vegetable cultivation. A wide gap exists between the yields obtained and the potential yields. By adopting improved varieties and technologies, production and productivity of vegetables can be increased. Promotion of hybrid vegetable technology or improved varieties is major strategy for increasing productivity. The major constraints could be detected to vegetable production technology like lack of knowledge about improved knowledge of IPM and technologies, unavailability of improved seeds of 
vegetables, lack of irrigation facilities, nonremunerative price, lack of training about scientific vegetable production technology, lack of subsidy and high costs of pesticides.

\section{Materials and Methods}

The present study was conducted in Nellore district of Andhra Pradesh in the year of 201819. Out of 43 mandals, only 5 mandals (Venkatagiri, Balayapalli, Ojili, Dakkili and Naidupeta) was purposely selected. From these mandals 12 villages were randomly selected, from these villages 8 vegetables growers were selected from each village by simple random sampling method. Thus the total numbers of 96 vegetables growers were selected.

A well-structured and pre tested schedule was used to collect information from the vegetables growers after having through consultation with experts. The interview schedule used under this study was having 20 statements regarding different constraints of vegetables production technology. The responses obtained towards these statements were recorded. The statement answered 'Yes' was given one mark and the statement having 'No' was given zero mark. Thus the maximum obtainable mark of each individual vegetables grower was 20 and minimum was zero.

\section{Results and Discussion}

The present investigation attempt was to categories the major constraints viz. technological, resource, market and miscellaneous constraints faced by farmers in vegetables production technology.

\section{Technological constraints of vegetable production technology}

Table 1 reveals that the lack of knowledge of IPM technologies $(91.66 \%)$ is the first technological constraint. The second and third constraints were lack of knowledge about improved varieties, seed rate and sowing time $(85.42 \%)$ and non- availability of facilities of soil testing $(81.25 \%)$. The other technological constraints were lack of training of scientific vegetable production technology (69.79\%) and lack of publication (64.58\%).

These finding were found to partially supported by the reports of earlier investigators

\section{Resource constraints of vegetable production technology}

Table 2 reveals that the lack of irrigation facilities $(94.79 \%)$ and high costs of pesticides $(90.62 \%)$ were the most important resource constraints mentioned by the vegetable growers. The other resource constraints were lack of cold storage (88.54\%), unavailability of improved seeds of vegetables $(86.45 \%)$ and scattered and small size land holding $(85.41 \%)$.

\section{Market constraints of vegetables production technology}

Table 3 indicates that non-remunerative price was found to be the first market constraint expressed by 95.83 per cent of the vegetable growers. The second market constraint which was expressed by vegetable growers was Poor marketing facilities resulting high risk $(87.50 \%)$. Markets are distantly locate (78.12\%) was third constraint. The fourth and fifth constraints expressed by vegetable growers were lack of transportation facilities and high charges $(75.00 \%)$ and approach roads not in good conditions $(70.83 \%)$.

\section{Miscellaneous constraints of vegetables production technology}

As far as the miscellaneous constraints are concerned, Table 4 shows that the first 
miscellaneous constraint expressed by 91.66 per cent of the vegetables grower was lack of subsidy followed by High risk of natural hazards $(85.41 \%)$, lack of information sources of vegetables production technology at village level (83.33\%), poor extension contact (75.00\%), non-availability of labour during peak season and high wages (36.66\%).

Table.1 Technological constraints of vegetable production

\begin{tabular}{|c|c|c|c|c|c|c|c|}
\hline S. & \multicolumn{4}{|c|}{ Technological } & Freq- & $\%$ & Rank \\
\hline No & \multicolumn{3}{|c|}{ Constraints } & & uency & age & \\
\hline \multicolumn{8}{|l|}{ - } \\
\hline \multirow[t]{4}{*}{1.} & Lack & of & \multicolumn{2}{|c|}{ knowledge } & 82 & 85.42 & II \\
\hline & about & & \multicolumn{2}{|c|}{ improved } & & & \\
\hline & \multicolumn{4}{|c|}{ varieties, seed rate and } & & & \\
\hline & \multicolumn{4}{|c|}{ sowing time } & & & \\
\hline \multirow[t]{3}{*}{2.} & Lack & of & \multicolumn{2}{|c|}{ knowledge } & 88 & 91.66 & I \\
\hline & about & & & IPM & & & \\
\hline & \multicolumn{3}{|c|}{ technologies } & & & & \\
\hline \multirow[t]{3}{*}{3.} & Lack & of & training & of & 67 & 69.79 & IV \\
\hline & \multicolumn{2}{|c|}{ scientific } & \multicolumn{2}{|c|}{ vegetable } & & & \\
\hline & \multicolumn{4}{|c|}{ production technology } & & & \\
\hline \multirow[t]{2}{*}{4.} & Non- & avi & lability & of & 78 & 81.25 & III \\
\hline & \multicolumn{4}{|c|}{ facilities of soil testing } & & & \\
\hline 5. & \multicolumn{4}{|c|}{ Lack of publication } & 62 & 64.58 & V \\
\hline
\end{tabular}

Table.2 Resource constraints of vegetable production technology

\begin{tabular}{|c|c|c|c|c|}
\hline Sr. & Resource & Frequency & $\%$ & Rank \\
\hline No. & Constraints & & age & \\
\hline \multirow[t]{3}{*}{1.} & Unavailability of & 83 & 86.45 & IV \\
\hline & improved seeds of & & & \\
\hline & vegetables & & & \\
\hline \multirow[t]{2}{*}{2.} & High costs of & 87 & 90.62 & II \\
\hline & pesticides & & & \\
\hline \multirow[t]{2}{*}{3.} & Lack of irrigation & 91 & 94.79 & I \\
\hline & facilities & & & \\
\hline \multirow[t]{3}{*}{4.} & Scattered and & 82 & 85.41 & V \\
\hline & small size land & & & \\
\hline & holding & & & \\
\hline \multirow[t]{2}{*}{5.} & Lack of cold & 85 & 88.54 & III \\
\hline & storage & & & \\
\hline
\end{tabular}


Table.3 Market constraints of vegetables production technology

\begin{tabular}{|c|c|c|c|c|}
\hline Sr. & Market & Frequency & $\%$ & Rank \\
\hline No & Constraints & & Age & \\
\hline • & & & & \\
\hline \multirow[t]{4}{*}{1.} & Poor marketing & 84 & 87.50 & II \\
\hline & Facilities & & & \\
\hline & resulting high & & & \\
\hline & Risk & & & \\
\hline \multirow[t]{2}{*}{2.} & Markets are & 75 & 78.12 & III \\
\hline & distantly located & & & \\
\hline \multirow[t]{3}{*}{3.} & Approach roads & 68 & 70.83 & V \\
\hline & not in good & & & \\
\hline & Conditions & & & \\
\hline \multirow[t]{3}{*}{4.} & Non- & 92 & 95.83 & I \\
\hline & Remunerative & & & \\
\hline & Price & & & \\
\hline \multirow[t]{4}{*}{5.} & Lack of & 72 & 75.00 & IV \\
\hline & Transportation & & & \\
\hline & facilities and & & & \\
\hline & high charges & & & \\
\hline
\end{tabular}

Table.4 Miscellaneous constraints of vegetables production technology

\begin{tabular}{|r|l|c|c|c|}
\hline Sr. & Miscellaneous & Frequency & $\%$ & Rank \\
\hline No & constraints & & age & \\
\hline. & & & & \\
\hline \hline 1. & High risk of & 82 & 85.41 & II \\
\hline & natural hazards & & & \\
\hline 2. & Lack of subsidy & 88 & 91.66 & I \\
\hline 3. & Non-availability & 67 & 69.79 & V \\
\hline & of labour during & & & \\
\hline & peak season and & & & \\
\hline & high wages & & & \\
\hline 4. & Poor extension & 72 & 75.00 & IV \\
\hline & contact & & & \\
\hline 5. & Lack of & 80 & 83.33 & III \\
\hline & information & & & \\
\hline & sources of & & & \\
\hline & vegetables & & & \\
\hline & production & & & \\
\hline & technology at & & & \\
\hline & village level & & & \\
\hline \hline & & & & \\
\hline
\end{tabular}


Table. 5 Suggestion for adoption of improved vegetables production technology

\begin{tabular}{|c|c|c|c|c|}
\hline Sr. & Suggestion for & Frequency & $\%$ & Rank \\
\hline \multirow[t]{5}{*}{ No } & adoption of & & age & \\
\hline & improved & & & \\
\hline & vegetables & & & \\
\hline & production & & & \\
\hline & technology & & & \\
\hline \multirow[t]{2}{*}{1.} & Input should be & 82 & 85.41 & VII \\
\hline & provided timely & & & \\
\hline \multirow[t]{4}{*}{2.} & Demonstration & 84 & 87.50 & VI \\
\hline & should be & & & \\
\hline & conducted on & & & \\
\hline & their field & & & \\
\hline \multirow[t]{5}{*}{3.} & Technical & 88 & 91.66 & III \\
\hline & knowledge of & & & \\
\hline & IPM technologies & & & \\
\hline & should be & & & \\
\hline & provided & & & \\
\hline \multirow[t]{2}{*}{4.} & Financial & 91 & 94.80 & I \\
\hline & assistance & & & \\
\hline \multirow[t]{2}{*}{5.} & Irrigation & 90 & 93.75 & II \\
\hline & facilities & & & \\
\hline \multirow[t]{2}{*}{6.} & Marketing & 85 & 88.54 & V \\
\hline & facilities & & & \\
\hline \multirow[t]{2}{*}{7.} & Transportation & 75 & 78.12 & IX \\
\hline & facilities & & & \\
\hline \multirow[t]{6}{*}{8.} & Conducted & 80 & 83.33 & VIII \\
\hline & training & & & \\
\hline & programme of & & & \\
\hline & vegetable & & & \\
\hline & production & & & \\
\hline & technology & & & \\
\hline \multirow[t]{3}{*}{9.} & Frequent visit of & 86 & 89.58 & IV \\
\hline & extension & & & \\
\hline & workers & & & \\
\hline
\end{tabular}

Suggestion for adoption of improved vegetables production technology

The suggestions for increased adoption of vegetables production technologies are presented in Table 5. Most of vegetable grower suggested for financial assistance, irrigation facilities, technical knowledge of IPM technologies should be provided, frequent visit to extension workers, marketing facilities, demonstration should be conducted on their fields, input should be provided timely, conducted training programme of vegetable production technology and Transportation facilities. These were the major problems faced by the vegetables growers for adoption of scientific technologies.

It is concluded that Non-remunerative prices, Lack of irrigation facilities, lack of knowledge about IPM technologies and lack of subsidy were determined as major constraints in adoption of vegetable 
production technology in Nellore District of Andhra Pradesh.

Most of the farmers suggested that financial assistance, Irrigation facilities and Technical knowledge on IPM in vegetable production technology to enhance the productivity.

\section{References}

Meena, K.C. (2003). Constraints faced by the farmers in adoption of improved cultivation of cabbage in Udaipur district of Rajasthan. Indian Research Journal of Extension Education, 3 (2): 69-71.
Rai, D.P. and Singh, Bhupendra (2010). Extent of knowledge and constraints in cotton production technology in Madhya Pradesh. Indian Research Journal of Extension Education. 10 (2): 78-80.

Ram, D., Singh, M.K., Prasad, A., Pradhan, B. and Kumar, M. (2009). Constraints of crop productivity in Sikkim. Agricultural Extension Review. 21 (4): 14-16.

Sahu, R.P., Sachan, V.K., Singh, Raman Jeet and Singh, Khilendra (2009). Knowledge gap of farm women in vegetables cultivation. Journal of Communication Studies, 27 (2): 83-87.

\section{How to cite this article:}

Vinod Naik, D., M. Kavitha and Reddy, R.V.S.K. 2019. Constraints in Adoption of Vegetables Production Technology in Nellore District of Andhra Pradesh, India. Int.J.Curr.Microbiol.App.Sci. 8(08): 2931-2936. doi: https://doi.org/10.20546/ijcmas.2019.807.363 